\title{
CORRELATION , PATH COEFFICIENTS AND REGRESSION ANALYSIS IN SUMMER SQUASH.
}

\author{
Abdul-Jabbar I. Marie \\ Agric. College /Mosul Univ., Iraq
}

\author{
Ghurbat H. Mohammed* \\ Agric . College/Duhok Univ., Iraq
}

\begin{abstract}
Simple correlation coefficients were estimated among number of quantitative traits from an experimental data applied by RCB Design with three replications, involved two squash cultivars (Mulla-Ahmed and the hybrid Opal type-HED 103) and four different concentrations of $\mathrm{K}$ and IAA $\left(0.0,0.5,1.0,1.5 \mathrm{gl}^{-1}\right),(0.0,100$, $\left.200,300 \mathrm{mgl}^{-1}\right)$ respectively. In order to determine the best traits affecting on the yield, path coefficient analysis was used to divide the correlation coefficients of the yield with its components into direct and indirect effects. To determine the nature response of the different traits for both $\mathrm{K}$ and IAA, trend analysis was applied, in which mean squares were divided in a variance analysis table into linear, quadratic and cubic relationship. Significant correlation coefficients in a positive direction were obtained between the total yield and its contributing characters viz. (no . of female flowers, sex ratio, no. of fruits plant ${ }^{-1}$, fruit weight and early yield). Number of fruits plant ${ }^{-1}$ was characterized with highest direct effect on the total yield, whereas, the highest indirect effects resulted from no. of fruits through fruit weight and from no. of female flowers through the path of no. of fruits plant ${ }^{-1}$. Trend analysis revealed a significant quadratic order regression form between $\mathrm{K}$ concentrations with plant height and fruit weight, while the relation between IAA concentrations with no. of branches and early yield showed a significant effect at the second order equation form.
\end{abstract}

\section{INTRODUCTION}

A knowledge of the nature of association between yield and its components is of great necessary in any breeding programme. The extend and direction of association are measured by correlation coefficients. Correlation studies provide information that selecting one character will result in progress for all positively correlated characters. Many of the characters are correlated because of mutual association, positive or negative, with other characters. Chaudhury (1974) found a significant correlation between plant height and number of branches in cucumber. Vijay (1987) in correlation studies on melon, observed that yield plant ${ }^{-1}$ was reported to be positively correlated with the number of fruits, average fruits weight, stem length and fruit shape index. Abdullah et al. (2002) reported a positive phenotypic correlation between the total yield with plant length, number of leaves plant $^{-1}$ and leaf area in their study involved 5 lines of (Cucurbita moschata). Camacho et al. (2006) found a positive and significant phenotypic correlation between the total yield of pumpkin with each of average fruit weight number of fruits plant ${ }^{-1}$. Hazara et al. (2007) in their investigation of 36 pumpkin cultivars, observed that fruit weight and number of fruits plant ${ }^{-1}$ were positively and significantly correlated. Al-lela (2008) stated that number of fruits plant ${ }^{-1}$ had a highly directed and indirected effects on the total yield of summer squash *Part of M.Sc. thesis of the second investigator.

Received 20/6/2010 accepted 4/10/2010 
through various traits, so it can be submitted in a breeding programme to increase and improve the quantity of yield.

\section{MATERIALS AND METHODS}

The experiment was performed at College of Agriculture, Dohuk University, Iraq in 2006, to study correlation and path coefficients among different traits of summer squash, in addition to trend analysis. The experiment includes two cultivars of summer squash local cultivar Mullah Ahmed (No. 1) and Opal type-HED 103 (No. 2) and their response to four concentrations of each $\mathrm{K}(0.0,0.5,1.0,1.5) \mathrm{g} \mathrm{l}^{-1}$ and IAA at $(0.0,100,200,300) \mathrm{mg}^{-1}$. The treatments were arranged in a Factorial Experiment using Split Plot System within RCB Design with three replications. The varieties were considered as the main plot and the interactions between $\mathrm{K}$ and IAA concentrations were arranged in subplots The land was disc plowed, harrowed, and then divided into growing units consist of two ridges, each ridge $(4 \times 2.25 \mathrm{~m})$ of 12 plant, with $35 \mathrm{~cm}$ intra plant spaces. Other agricultural practices were similarly carried out to each experimental unit as followed by farmers in the area. Five plants were selected at random, and observations were recorded on 9 traits, viz. total yield, early yield, fruit weight, number of fruit plant $^{-1}$, sex ratio, fruit setting\%, number of female flowers and number of branches and plant height. Simple correlation coefficients between the total yield and its components and between each pair of components were estimated by the method of (Harvey, 1987). Then, correlation coefficients between yield and its components (fruit no. x1, fruit wt x2, no. of female flowers $\mathrm{x} 3$, no. of branches $\mathrm{x} 4$ and plant height $\mathrm{x} 5$ ) were divided into direct and indirect effects according to the method mentioned by (Al-Rawi, 1987) Fig.(1). Lenka and Mishra (1973) have suggested a scale for the importance of direct and indirect effects values as given below:

Values of direct and indirect effects

0.00-0.09

$0.10-0.19$

$0.20-0.29$

0.30-0.99

More than

\author{
Rate of scale \\ Negligible \\ Low \\ Moderate \\ High \\ Very high
}

Analysis of variance carried out according to the method of the used design, and trend analysis for $\mathrm{K}$ and IAA were done to partition their mean square to linear, quadratic and cubic degree of relationships for each trait, to select the best regression equations for predicting the value of each trait, through $\mathrm{K}$ and IAA separately.

All statistical analysis carried out with the help of (SAS V.9) (Statistical Analysis System, 2001). 
Mesopotomia J. of Agric. (ISSN 1815 - 316X) Vol. (38) No. (Supplement 1) 2010

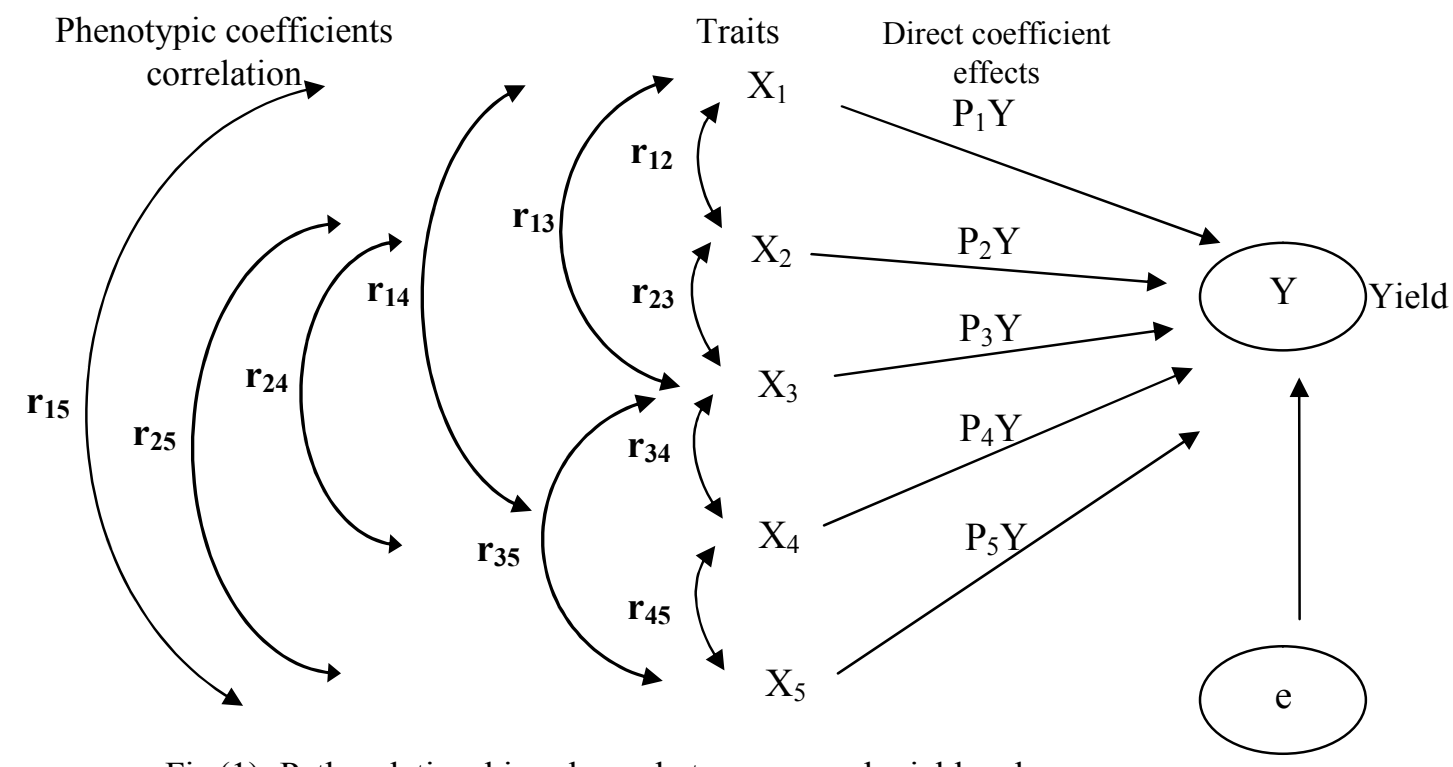

Fig (1): Path relationship scheme between squash yield and $\mathrm{x}_{1}, \mathrm{x}_{2}, \mathrm{x}_{3}, \mathrm{x}_{4}, \mathrm{x}_{5}$.

\section{RESULTS AND DISCUSSION}

Correlation between the total yield and its components: Table (1) revealed a positive and significant correlations between plant height and number of fruits plant ${ }^{-}$ ${ }^{1}(0.26)$. It is also observed a positive and significant correlation between number of branches with the early yield recorded (0.27). On the other hand, number of female flowers was significantly and positively correlated with total yield, early yield, number of fruits plant $^{-1}$ and sex ratio measured $(0.52,0.35,0.50 \& 0.54)$ respectively, whereas, it was negatively correlated with fruit setting percentage (0.57). Fruit setting $\%$ had a significant positive correlation with number of fruits plant $^{-1}(0.40)$. Sex ratio trait exhibited a positive and significant correlation with total yield (0.46), early yield (0.28) and number of fruits plant ${ }^{-1}(0.38)$. There was also positive significant correlation between number of fruits plant ${ }^{-1}$ with the total yield and early yield $(0.59 \& 0.37)$ respectively. The average fruit weight resulted in a positive and significant correlation with the total yield and early yield $(0.53,0.20)$, respectively. Finally early yield showed a positive and significant correlation with the total yield (0.46).

Table (1): Correlation coefficient between total yield and other traits.

\begin{tabular}{|c|c|c|c|c|c|c|c|c|}
\hline Traits & $\begin{array}{c}\text { Plant } \\
\text { Height }\end{array}$ & $\begin{array}{c}\text { No. of } \\
\text { Branches }\end{array}$ & \begin{tabular}{|c|}
$\begin{array}{c}\text { No. of Female } \\
\text { Flowers }\end{array}$ \\
\end{tabular} & \begin{tabular}{|c|} 
fruit \\
Setting $\%$ \\
\end{tabular} & Sex Ratio & \begin{tabular}{|c|} 
No. of \\
Fruits/ Plant \\
\end{tabular} & $\begin{array}{c}\text { Fruit } \\
\text { Weight }\end{array}$ & $\begin{array}{l}\text { Early } \\
\text { Yield } \\
\end{array}$ \\
\hline Total Yield & 0.105 & 0.163 & $* * 0.561$ & 0.14 & $* * 0.46$ & $* * 0.591$ & $* * 0.534$ & $* * 0.462$ \\
\hline Early Yield & 0.060 & $* * \mathbf{0 . 2 7 2}$ & $* * \mathbf{0 . 3 5 3}$ & -0.010 & $* * 0.283$ & $* * 0.374$ & $* 0.201$ & \\
\hline Fruit Weight & 0.143 & 0.040 & 0.051 & -0.122 & 0.190 & -0.100 & & \\
\hline $\begin{array}{cl}\text { No. of } \\
\text { Fruits/ Plant }\end{array}$ & $* * 0.264$ & 0.191 & $* * 0.502$ & $\begin{array}{c}* * \\
0.404\end{array}$ & $* * 0.385$ & & & \\
\hline Sex Ratio & 0.171 & 0.144 & $* * 0.545$ & -0.190 & & & & \\
\hline $\begin{array}{c}\text { fruit Setting } \\
\%\end{array}$ & 0.041 & 0.033 & $\begin{array}{c}* * \\
-0.576\end{array}$ & & & & & \\
\hline $\begin{array}{c}\text { No. of } \\
\text { Female Flowers } \\
\end{array}$ & 0.172 & 0.161 & & & & & & \\
\hline $\begin{array}{c}\text { No. of } \\
\text { Branches }\end{array}$ & 0.180 & & & & & & & \\
\hline
\end{tabular}


Shedding a light on the correlations between the principal character (total yield) and its components, it exhibited a significant correlation in the desired direction with number of female flowers, sex ratio, number of fruits plant ${ }^{-1}$, fruit weight and early yield as previously mentioned. This means that increasing these traits followed by increasing the total yield of plants.

Path Coefficient Analysis: Data reported in table (2) state the direct and indirect effects of correlation coefficients between the total yield and some affecting traites. It can be noticed that direct effects were positive for all traits except for fruit

Table(2): Estimation of path coefficient analysis for some studied traits on the total yield.

\begin{tabular}{|l|c|c|}
\hline \multicolumn{1}{|c|}{ Traits } & \multicolumn{2}{c|}{ Path coefficient values } \\
\hline 1- Effect of fruit number plant-1 on yield: & $\mathrm{p} 1 \mathrm{y}$ & 0.158 \\
\hline Direct effect & $\mathrm{r} 12 \mathrm{p} 2 \mathrm{y}$ & -0.133 \\
\hline Indirect effect through fruit weight & $\mathrm{r} 13 \mathrm{p} 3 \mathrm{y}$ & 0.431 \\
\hline Indirect effect through number of female flowers & $\mathrm{r} 14 \mathrm{p} 4 \mathrm{y}$ & 0.162 \\
\hline Indirect effect through number of branches & $\mathrm{r} 15 \mathrm{p} 5 \mathrm{y}$ & -0.027 \\
\hline Indirect effect through plant length & $\mathrm{rly}$ & 0.591 \\
\hline Sum of total effect & & \\
\hline 2- Effect of fruit weight on yield: & $\mathrm{p} 2 \mathrm{y}$ & -0.028 \\
\hline Direct effect & $\mathrm{r} 21 \mathrm{p} 1 \mathrm{y}$ & 0.480 \\
\hline Indirect effect through fruits number & $\mathrm{r} 23 \mathrm{p} 3 \mathrm{y}$ & 0.149 \\
\hline Indirect effect through number of female flowers & $\mathrm{r} 24 \mathrm{p} 4 \mathrm{y}$ & -0.060 \\
\hline Indirect effect through number of branches & $\mathrm{r} 25 \mathrm{p} 5 \mathrm{y}$ & -0.007 \\
\hline Indirect effect through plant length & $\mathrm{r} 2 \mathrm{y}$ & 0.534 \\
\hline Sum of total effect & & \\
\hline 3- Effect of number of female flowers on yield: & $\mathrm{p} 3 \mathrm{y}$ & 0.043 \\
\hline Direct effect & $\mathrm{r} 31 \mathrm{p} 1 \mathrm{y}$ & 0.210 \\
\hline Indirect effect through fruits number & $\mathrm{r} 32 \mathrm{p} 2 \mathrm{y}$ & -0.065 \\
\hline Indirect effect through fruit weight & $\mathrm{r} 34 \mathrm{p} 4 \mathrm{y}$ & 0.390 \\
\hline Indirect effect through branches number & $\mathrm{r} 35 \mathrm{p} 5 \mathrm{y}$ & -0.017 \\
\hline Indirect effect through plant length & $\mathrm{r} 3 \mathrm{y}$ & 0.561 \\
\hline Sum of total effect & $\mathrm{p}$ & \\
\hline 4- Effect of branches number on yield: & $\mathrm{p} 4 \mathrm{y}$ & 0.075 \\
\hline Direct effect & $\mathrm{r} 41 \mathrm{p} 1 \mathrm{y}$ & 0.032 \\
\hline Indirect effect through fruits number & $\mathrm{r} 42 \mathrm{p} 2 \mathrm{y}$ & -0.016 \\
\hline Indirect effect through fruit weight & $\mathrm{r} 43 \mathrm{p} 3 \mathrm{y}$ & -0.038 \\
\hline Indirect effect number through female flowers & $\mathrm{r} 45 \mathrm{p} 5 \mathrm{y}$ & 0.110 \\
\hline Indirect effect through plant length & $\mathrm{r} 4 \mathrm{y}$ & 0.163 \\
\hline Sum of total effect & $\mathrm{r} 51 \mathrm{p} 1 \mathrm{y}$ & 0.098 \\
\hline 5- Effect of plant height on yield: & $\mathrm{r} 53 \mathrm{p} 3 \mathrm{y}$ & -0.011 \\
\hline Direct effect & $\mathrm{r} 54 \mathrm{p} 4 \mathrm{y}$ & 0.029 \\
\hline Indirect effect through fruits number & 0.105 \\
\hline Indirect effect through fruit weight & & \\
\hline Indirect effect number through female flowers & & \\
\hline Indirect effect through branches number & & \\
\hline Sum of total effect & & \\
\hline
\end{tabular}


weight. Number of fruits plant ${ }^{-1}$ was characterized with low but highest direct effect. Similar results were reported by Nandpuri et al., (1977) and Al-Hubaity (1996) in tomato , Al-lela (2008) in summer squash. Concerning the indirect effects, it is obviously noticed that no. of fruits plant ${ }^{-1}$ revealed a highest indirect effect on the yield (0.480) fruit weight, followed by number of female flowers $(0.431)$ through the path no. fruits plant ${ }^{-1}$. While number of bramches and fruits number showed a positive indirect effects $(0.390,0.210)$ through the path of number of female flowers respectively. On the other hand, no. of female flowers had a positive indirect effect (0.149) on the total yield through fruit weight. Whereas, the remnant traits revealed low indirect effects (positive or negative). The final conclusion from these results revealed that no. fruits plant ${ }^{-1}$ had highest direct effect on the yield, inspite of low (0.158), in addition it had positive and important indirect effects through all the remnant traits, whereas, it was high and moderate with two of them $(0.480$ and 0.210$)$ respectively. So it can be considered this trait as a selection index on the high yield in breeding program.

Trend Analysis: From trend analysis results, it is obviously shown that the relation from the second order was significant for the $\mathrm{K}$ relation with plant height, whereas it was from the first order for the IAA relation with the same trait. So the suitable regression equation to predict plant height is quadratic and liner respectively as illustrated in Figs.(2a \& 2b).

Hence, Fig. 2a revealed that the best plant height was approximately $58 \mathrm{~cm}$ at $\mathrm{K}$ concentration $0.55 \mathrm{gl}^{-1}$.

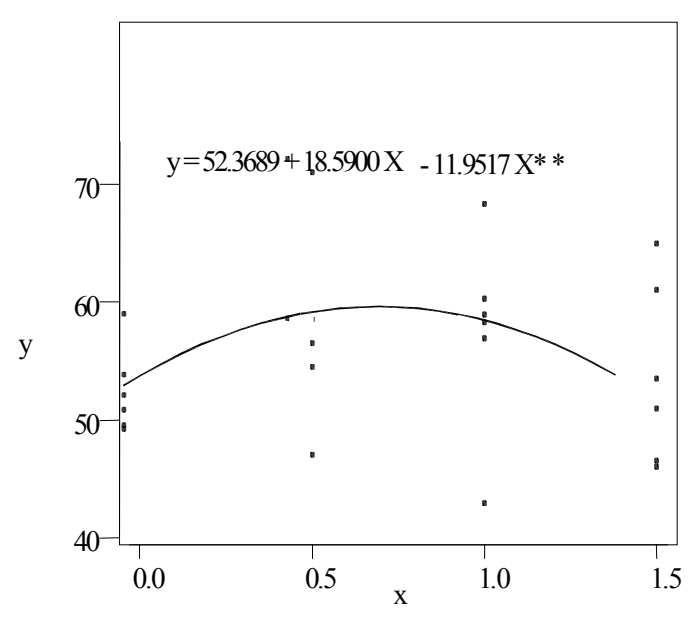

Figure(2a): The effect of $\mathrm{K}$ rates $\mathrm{gl}-^{1}(\mathrm{x})$ on squash Plant height $\mathrm{cm}(\mathrm{y})$

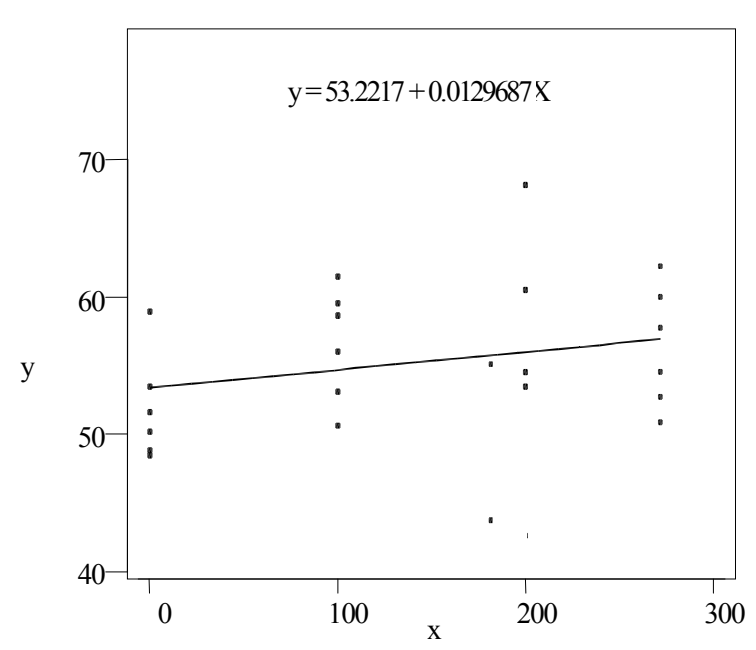

Figure (2b): The effect of IAA rates ppm(x) on squash plant height $\mathrm{cm}(\mathrm{y})$

In case of the relation between $\mathrm{K}$ concentrations and number of branches plant $^{-1}$ (Fig.3a), was from the first order regression form. While the relation between IAA concentrations and this trait was significant from the second order, so favorable regression equation for predicting number of branches is linear and quadratic respectively Figs. (3a \& 3b). Figure (3b) illustrates that the best number of branches was 2.5 at the concentration 180 . 


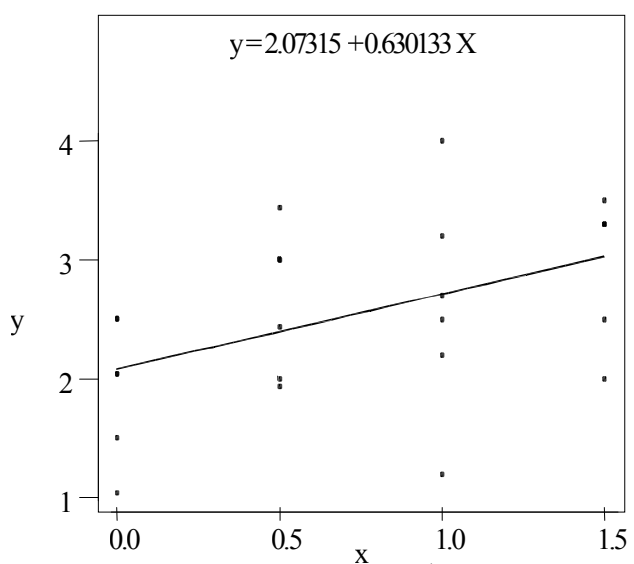

Figure (3a): The effect oK rates gl- $-1 x$ ) on squash branchesmmbers per plant (y)

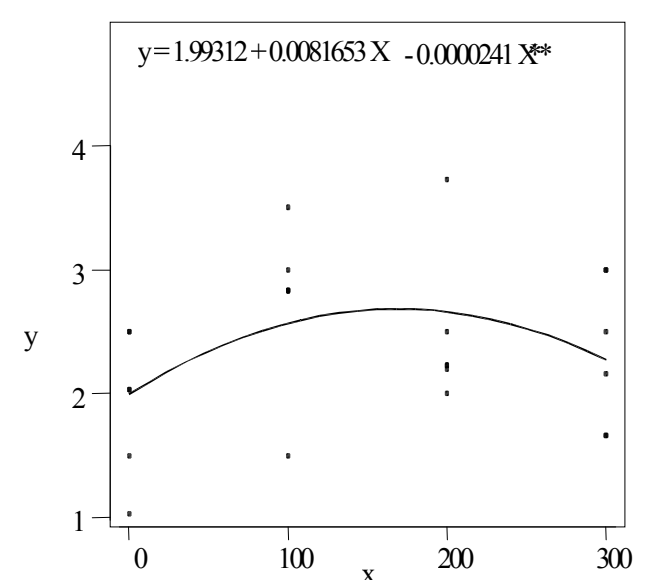

Figure (3b): The effect of IAArates ppm(x) on squash branches numbers per plant (y)

Fig $(4 a, 4 b)$ revealed the relation between $\mathrm{K}$ and IAA concentrations with number of fruits plant ${ }^{-1}$ were from the first order. And the fit regression equation to predict no. of fruits plant ${ }^{-1}$ is linear for both $\mathrm{K}$ and IAA concentrations
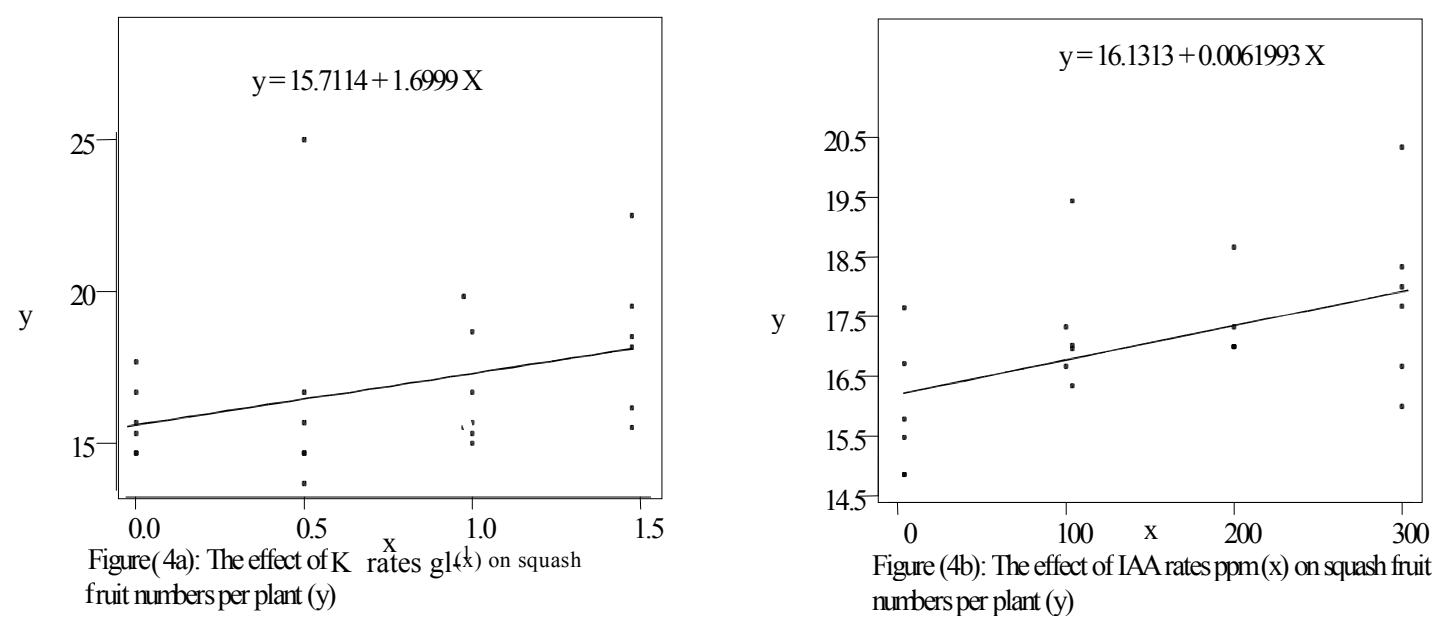

Fig (5) obviously exhibited a significant quadratic form from the second order between $\mathrm{K}$ concentrations and average fruit weight. Whereas, the relation was from the first order between IAA concentrations and this trait. So the suitable regression equation to predict fruit weight is quadratic and linear respectively as shown in Fig. (5a \& 5b). In addition as exhibited in Fig. (5a) that the best fruit

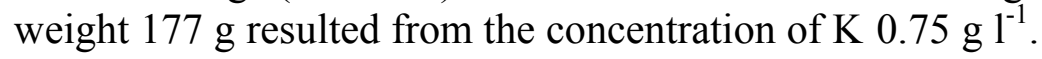




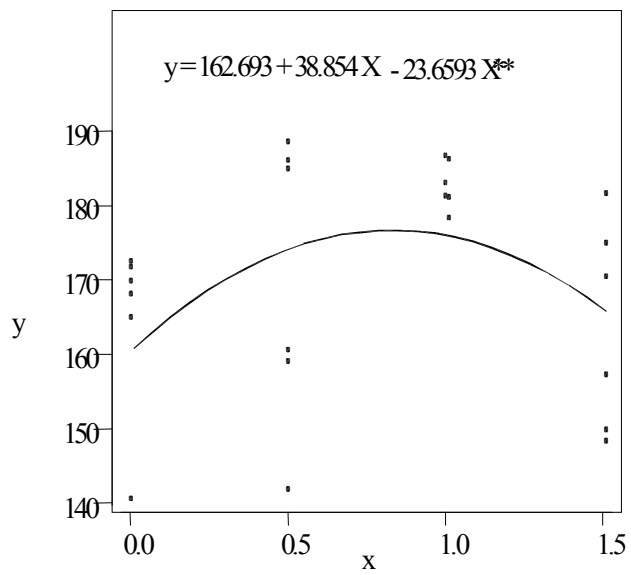

Figure(5a): The effect of $\mathrm{K}$ rates $\mathrm{gl}^{-1}$ (x) on squash fruit weight $g(y)$

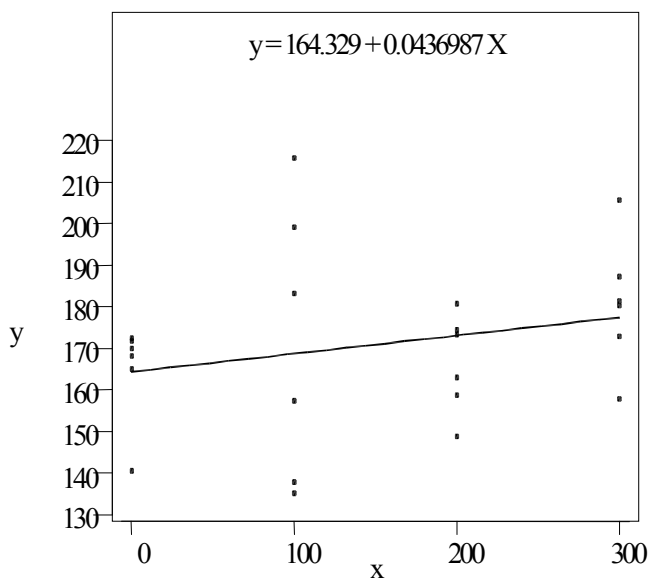

Figure (5b): The effect of IAArates ppm(x) on squash fruit weight $g(y)$

Fig (6) indicates a significant relation from the first order between $\mathrm{K}$ concentrations and early yield. But the relation was significant from the second order between IAA concentrations and with this trait. So the suitable regression equation to predict early yield is linear and quadratic respectively. The best early yield was nearly $0.43 \mathrm{~kg} \mathrm{pant}^{-1}$ at IAA concentration $220 \mathrm{ppm}$.

$y-0.68$ । chomas:k3 X

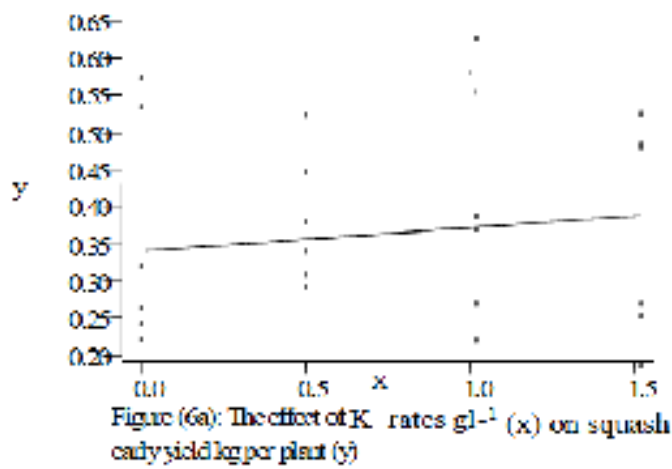

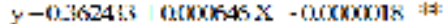

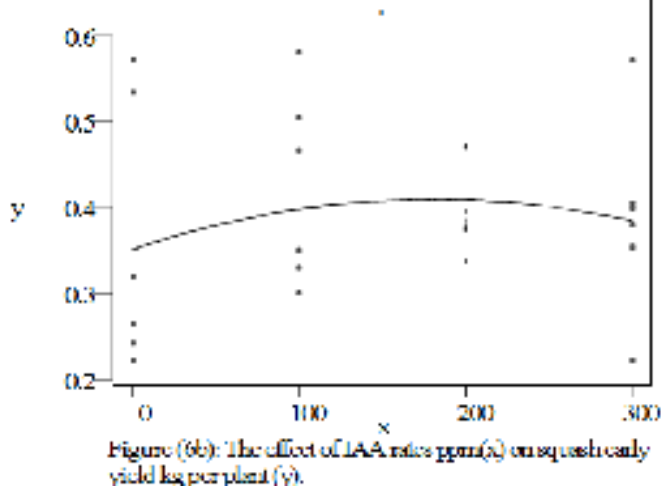

Regarding the relation between $\mathrm{K}$ and IAA concentrations with the total yield (fig.7) shows a significant relation from the first order And the suitable regression equation to predict the total yield is linear for both $\mathrm{K}$ and IAA concentrations.
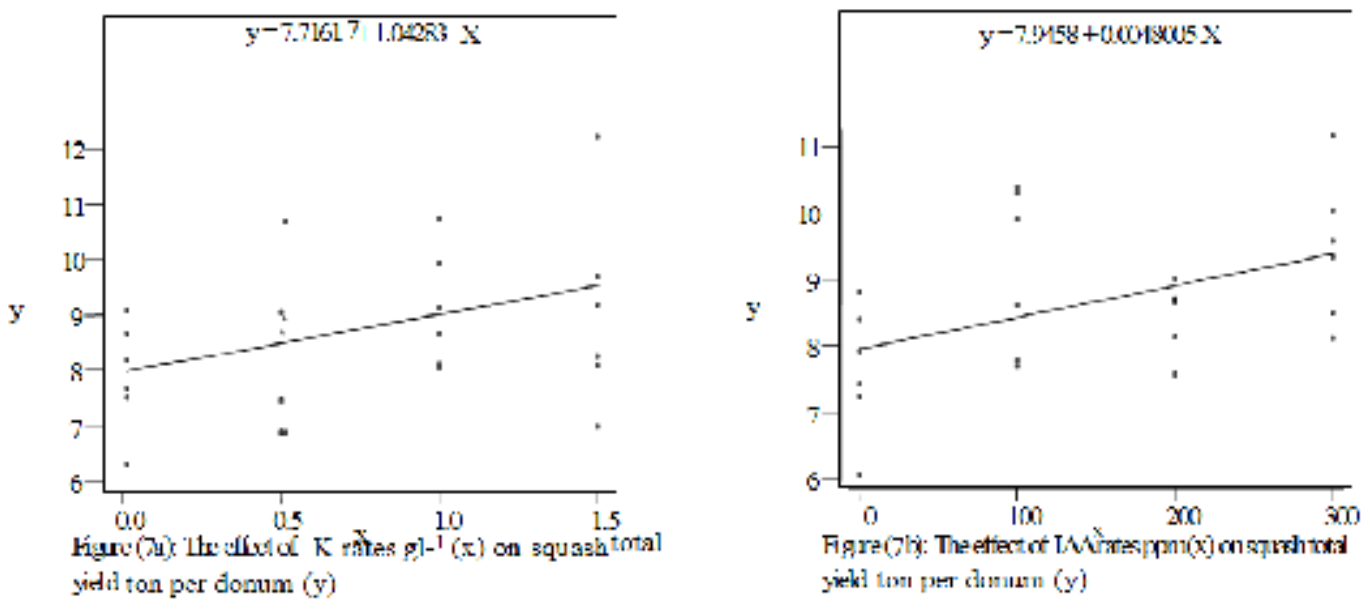

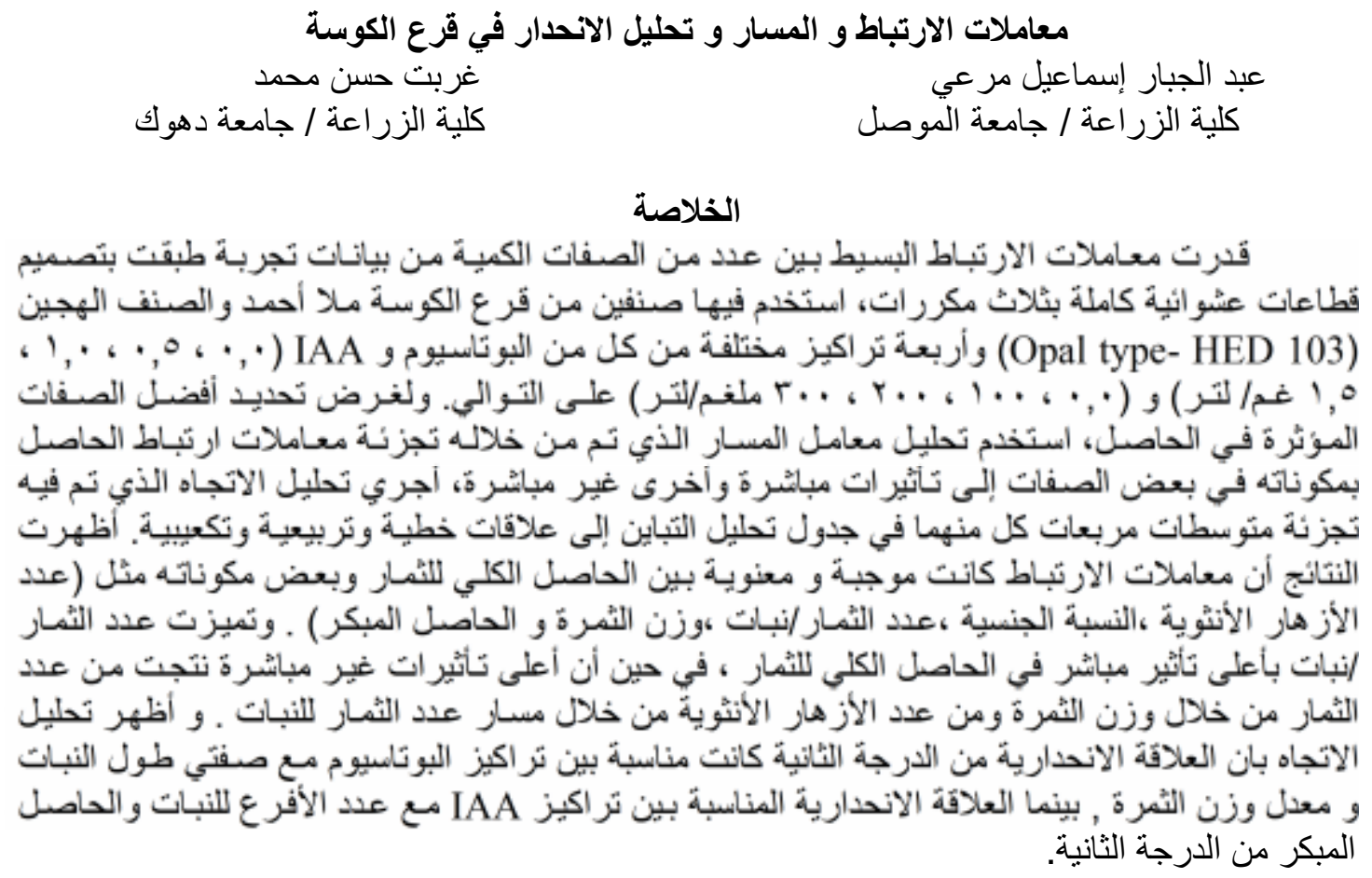

\section{REFERENCES}

Abdullah, A.A; H. H. Hegazi and A. A. Ibrahim (2002). Evaluation of Locally-grown pumpkin genotypes in the central region of Saudia Arabia. J. King Saud Univ., Agric. Sci., Riyadh.15(1):13-24.

AL-Hubaity A. J. I. (1996). Study the combining ability, heterosis and path coefficient analysis in tomato (Lycopersicon esculentum Mill.) $\mathrm{Ph}$. D. thesis. College of Agriculture and Forestry. Mosul Univ. Iraq.

Al-lela, W. B. M. (2008). Analysis of combining ability, heterosis and correlation in growth and yield of summer squash (Cucurbita pepo L.). M. Sc. Thesis, College of Agriculture and forestry, Mosul University, Iraq (In Arabic).

Al-Rawi K. M. (1987). Introduction to Variance Analysis. Directorate of Book House of Publishing and Pressing. Mosul Univ, Iraq. (In Arabic).

Camacho, M. E.; F. A. Cabrera and D. B. Garcia (2006). Phenotypic, genotypic and environmental correlations in (Cucurbita moschata Duch. Ex poir). Rev. Fac. Nal. Agr. Medellin, 59(1): 1-14.

Chaudhary, B. R. ; M. S. Fageria and R. S. Dhaka (1974). Corration and path coefficient analysis in muskmelon (Cucumis melo L.). Indian J. of Horticulture, 6 (2): 303- 329.

Harvey, W. A. (1987). Introduction for use of LSMLGP (least Square and Maximum likehood, General Purposes Program). Ohio State Univ., U. S. A.

Hazara, P.; A. K. Mandal; A. K. Dutta; D. Sikadar and M. K. Pandit (2007). Breeding pumpkin(Cucurbita moschata Duch. Ex poir) for high yield and carotene. Acta Hort. 725: 431-435.

Lenka, D. and B. Mishra (1973). Path coefficient analysis of yield in rice varieties. Indian J. Agric. Sci., 43: 376-379.

Nandpuri, K. S.; J. S. Kinwar and L. Rosshan (1977). Variability path analysis and discriiminant function selection in tomato. Haryana J. Hort. Sci., 6 (1/2): 73-78.

SAS (2001). SAS/STAT 'User's Guide for Personal Computer. Release 6.12. SAS Institute Inc, Cary, NC., U S A.

Vijay, O. P. (1987). Genetic variabitity correlation, and path-analysis in muskmelon (Cucumis melo L.). Indian J. Hort, 44: 233-238. 